\title{
懸濁点眼剤の物理的な安定性に及ぼす保管期間の影響
}

\author{
中田雄一郎, ${ }^{*, a}$ 山 口 瑞 季, ${ }^{b}$ 出口粧央里, ${ }^{b}$ 稲 葉 一 訓, ${ }^{b}$ 長 井 紀 章 $b$
}

\section{Effect of Shelf Life on the Physical Stability of Suspended Ophthalmic Solutions}

\author{
Yuichiro Nakada, ${ }^{*, a}$ Mizuki Yamaguchi, ${ }^{b}$ Saori Deguchi, ${ }^{b}$ Kazunori Inaba, ${ }^{b}$ and Noriaki Nagai ${ }^{b}$ \\ ${ }^{a}$ Faculty of Pharmacy, Osaka-Ohtani University; 3-11-1 Nishikiorikita, Tondabayashi, Osaka 584-8540, Japan: \\ and ${ }^{b}$ Faculty of Pharmacy, Kindai University; 3-4-1 Kowakae, Higashi-Osaka, Osaka 577-8502, Japan.
}

(Received January 10, 2021; Accepted March 6, 2021)

\begin{abstract}
Quality changes associated with physical changes in suspended eye drops are difficult to predict. In this study, we attempted to evaluate the aggregation and redispersability in commercially available suspended eye drops (fluorometholone ophthalmic solutions). The $0.1 \%$ fluorometholone ophthalmic solutions (the original product and 4 generic products) were gently mixed by hand after short-term (4 months) or long-term (40 months) storage, and the drug concentration in the first drop and physical stability (redispersability and particle size) were measured. All eye drops produced a cloudy precipitate on the bottom surface of the container, and the amount of precipitate decreased with mixing time. The drug concentration per drop in the original product was approximately $70 \%$ of the labeled value after mixing 10 times, and the drug particle size was approximately $4 \mu \mathrm{m}$. After mixing the generic products stored short-term 10 times, the concentration ranged from less than $50 \%$ to almost $100 \%$. In addition, some generic products after long-term storage had a reduced redispersion ability and labeled concentration. These results suggested that at least 10 mixing were required before the using of fluorometholone original product. In addition, some generic products may not provide sufficient drug exposure even when mixed in the same manner as the original products.
\end{abstract}

Key words — suspended ophthalmic solution; redispersibility; storage period; generic product; drug concentration; particle size

\section{緒言}

医薬品にとって品質は有効性，安全性と同様に重 要である.これら医薬品の品質に及ぼす影響には化 学的な影響, 物理的な影響に加え, 微生物によって 変質する生物学的な影響が挙げられる。一般に，製 剂の化学的変化は, 加速試験や苛酷試験で推定可能 であり, 生物学的要因はカビや微生物の有無を確認 することで評価可能である。，一方，薬物粒子の凝集 や再分散性といつた物理的変化は, 化学的変化や生 物学的要因による変化と異なり予測することが難し いのが現状である.

眼科領域において, 物理的評価の検証が品質に大 きく影響するとされる製剤として懸濁製剤中の薬物 粒子の分散安定性がある。点眼剤に供される薬物の 中には水に対する溶解度が低い薬物も多く，水性懸

\footnotetext{
$a$ 大阪大谷大学薬学部, $b$ 近畿大学薬学部
}

*e-mail: nakadayu@osaka-ohtani.ac.jp
濁点眼剤や眼軟膏剤が剤形として選択されている. この水性懸濁点眼剂は難溶性薬剂の微細結晶や微粉 末を水性媒体に懸濁させた水性製剤であり，眼軟膏 に比べて点眼手法が容易であり, 点眼時の不快感も 少ないという特徵を有している. しかし，水性懸濁 点眼剂では懸濁された薬物が時間とともに沈降する ため, 薬物の沈降速度を遅くするとともに, 薬物の 沈降によって堆積層が形成された場合には，簡単な 振とうや攪汼によって均一な懸濁液に戻る特性（再 分散性/再懸濁性）が求められている.さらに懸濁 製剂は，保存中に分散粒子が成長し粒子径が変化す ると生物効果に影響すること1)や容器への凝集魂の 固着が知られており，これらは点眼液 1 滴中の薬物 濃度を変化させ，有効性に直接影響することが容易 に類推できる.

懸濁点眼剂には多くの種類が用いられているが, なかでもフルオロメトロン点眼液 $0.1 \%$ （以下， FML0.1 と略称）は強い局所消炎作用を持つが，眼 圧上昇作用が他のステロイドに比べ弱く, 眼科領域 
Table 1. Composition and Lot of FML 0.1 Used in This Study

\begin{tabular}{|c|c|c|c|}
\hline \multicolumn{2}{|c|}{ Formulation } & Lot (Expiration Date) & Additives \\
\hline Original & $\begin{array}{l}4 \text { M-storage } \\
40 \text { M-storage }\end{array}$ & $\begin{array}{l}\text { 1FM6333 (Sep., 2022) } \\
\text { 1FM6072 (Jul., 2019) }\end{array}$ & $\begin{array}{l}\text { Sodium edetate hydrate, Sodium chloride, Benzalkonium chloride, Sodium } \\
\text { dihydrogen phosphate hydrate, Polysorbate } 80 \text {, Methylcellulose, Sodium } \\
\text { hydrogen phosphate hydrate }\end{array}$ \\
\hline Generic A & $\begin{array}{l}4 \text { M-storage } \\
40 \text { M-storage }\end{array}$ & $\begin{array}{l}\text { P468 (Jul., 2022) } \\
\text { K302 (Oct., 2019) }\end{array}$ & $\begin{array}{l}\text { Methylcellulose, Benzalkonium chloride, Sodium hydrogen phosphate hydrate, } \\
\text { Sodium chloride, Hydrochloric acid }\end{array}$ \\
\hline Generic B & $\begin{array}{l}4 \text { M-storage } \\
40 \text { M-storage }\end{array}$ & $\begin{array}{l}\text { G110 (Feb., 2022) } \\
\text { B850 (Oct., 2019) }\end{array}$ & $\begin{array}{l}\text { Sodium chloride, Benzalkonium chloride, Polysorbate } 80 \text {, Sodium edetate } \\
\text { hydrate, Sodium hydrogen phosphate hydrate, Sodium dihydrogen phosphate } \\
\text { hydrate, Polyvinyl alcohol (partially saponified) }\end{array}$ \\
\hline Generic C & $\begin{array}{l}4 \text { M-storage } \\
40 \text { M-storage }\end{array}$ & $\begin{array}{l}\text { L19902 (Feb., 2022) } \\
\text { L16909 (Sep., 2019) }\end{array}$ & $\begin{array}{l}\text { Polysorbate } 80 \text {, Benzalkonium chloride, Anhydrous sodium nonhydrogen } \\
\text { phosphate, Anhydrous sodium dihydrogen phosphate, Tonicity agent }\end{array}$ \\
\hline Generic D & $\begin{array}{l}4 \text { M-storage } \\
40 \text { M-storage }\end{array}$ & $\begin{array}{l}9535 \text { (Nov., 2022) } \\
6377 \text { (Sep., 2019) }\end{array}$ & $\begin{array}{l}\text { Potassium dihydrogen phosphate, Sodium hydrogen phosphate hydrate, } \\
\text { Sodium chloride, Benzalkonium chloride, Methylcellulose }\end{array}$ \\
\hline
\end{tabular}

でよく使用される代表的な懸濁点眼剤である。また 後発品が多く流通されているのも大きな特徵であ る。今回，これら FML0.1を用いて，異なる期間 保管した際の物理的な安定性 (再分散性及び粒子径) を評価するとともに，混和後の初回 1 滴中のフルオ ロメトロン（FML）濃度変化について検討した.

$$
\text { 方法 }
$$

1. 試料実験には臨床で用いられている先発 品 1 種と後発品 4 種（後発品 $\mathrm{A}-\mathrm{D}$ ) の計 5 種の FML0.1 を選択した.これら点眼液を, 研究室の保 管棚に未開封の状態で 4 力月（短期保管）及び 40 力月間（長期保管）正立静置保存し，その後の 懸濁粒子の状態を評価した。なお長期保管品は物理 化学的な変化を明確に観察するために使用期限を超 えた 40 カ月保管品を使用した。この際，保管温度 は実際の使用を想定し成り行き（室温）とした。

Table 1 には今回実験に使用した 5 種の FML0.1の Lot や処方内容を示す。試験は 2020 年 6-8 月に実 施した.

2. 再分散性試験再分散性の確認は試験者 （男性 61 歳，女性 23 歳）の肘を机に固定し，人差 し指と親指で点眼容器のキャップ上部と底面を挟む ように軽く持ち, 点眼容器をゆっくりと約 $45-90^{\circ}$ の角度で $2 ， 3 ， 5,10$ 回手振りし（手振り混和）, 容器固着と白濁性を目視観察することで実施した. 目視観察は Fig. 1 に示すように, 固化沈殿物の容 器底面に対する面積割合を 0 から+5の 6 段階で評

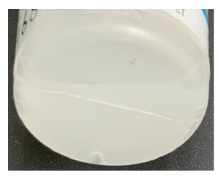

$+0$

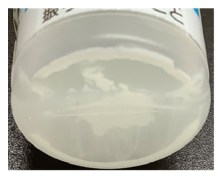

$+3$

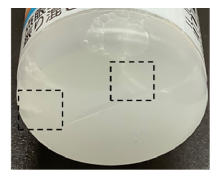

$+1$

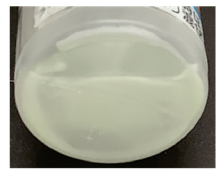

$+4$

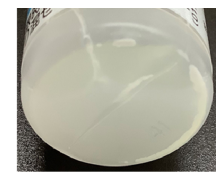

$+2$

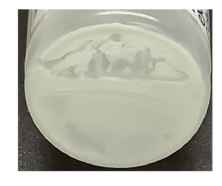

$+5$
Fig. 1. Evaluation Score for Precipitation in the Bottle of FML0.1

There are precipitates in the area surrounded by the dotted line. (Color figure can be accessed in the online version.)

価した。具体的には「0」はほぼ固化沈殿物なし, $「+1 」$ は 1 割未満,「+2」は 1-2 割程度,「+3」 は 3-4 割程度,「+4」は 5-7 割程度,「+5」は 8 割以上を目安とした。

3. 点眼液中薬物粒子の観察と粒度分布の測定 室温下で短期及び長期保管した点眼液に対し， 2. で示した手振り混和を 2-10 回行い, 点眼瓶から 1 滴滴下した液中の粒子状態を観察した。粒子状態は 光学顕微鏡 BA210E（島津製作所，京都）にて観察 することで評価した．また，薬物粒度分布及び平均 粒子径はレーザ回折式粒度分布測定装置 SALD7100 （島津製作所，京都）にて測定した。実験は 3 回以上繰り返し，再現性があることを確認した。

4. HPLC 法によるFML の定量法上記 3 . で示した同様の方法にて，短期及び長期保管した点 


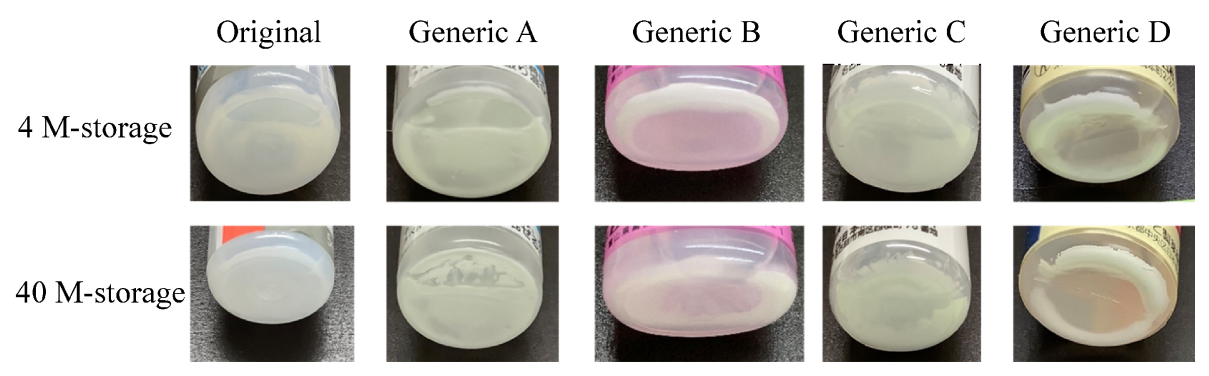

Fig. 2. Image of FML0.1 Stored for $4 \mathrm{M}$ and $40 \mathrm{M}$ (Color figure can be accessed in the online version.)

Table 2. Precipitation and Redispersability in the FML0.1 Stored for $4 \mathrm{M}$ and $40 \mathrm{M}$

\begin{tabular}{|c|c|c|c|c|c|}
\hline \multirow{2}{*}{\multicolumn{2}{|c|}{ Formulation }} & \multicolumn{4}{|c|}{ Number (Count) } \\
\hline & & 2 & 3 & 5 & 10 \\
\hline \multirow[t]{2}{*}{ Original } & \multirow{2}{*}{$\begin{array}{l}4 \mathrm{M} \text {-storage } \\
40 \mathrm{M} \text {-storage }\end{array}$} & $+0,+0,+1$ & $+0,+0,+0$ & $+0,+0,+0$ & $+0,+0,+0$ \\
\hline & & $+0,+4,+1$ & $+0,+2,+0$ & $+0,+0,+0$ & $+0,+0,+0$ \\
\hline \multirow[t]{2}{*}{ Generic A } & \multirow{2}{*}{$\begin{array}{l}4 \mathrm{M} \text {-storage } \\
40 \mathrm{M} \text {-storage }\end{array}$} & $+0,+0,+0$ & $+0,+0,+0$ & $+0,+0,+0$ & $+0,+0,+0$ \\
\hline & & $+4,+4,+5$ & $+4,+3,+3$ & $+1,+0,+2$ & $+0,+0,+0$ \\
\hline \multirow[t]{2}{*}{ Generic B } & \multirow{2}{*}{$\begin{array}{l}4 \mathrm{M} \text {-storage } \\
40 \mathrm{M} \text {-storage }\end{array}$} & $+4,+4,+4$ & $+3,+4,+4$ & $+1,+3,+3$ & $+0,+2,+2$ \\
\hline & & $+4,+4,+4$ & $+3,+3,+3$ & $+1,+2,+2$ & $+0,+1,+1$ \\
\hline \multirow[t]{2}{*}{ Generic C } & \multirow{2}{*}{$\begin{array}{l}4 \mathrm{M} \text {-storage } \\
40 \mathrm{M} \text {-storage }\end{array}$} & $+0,+0,+0$ & $+0,+0,+0$ & $+0,+0,+0$ & $+0,+0,+0$ \\
\hline & & $+0,+0,+0$ & $+0,+0,+0$ & $+0,+0,+0$ & $+0,+0,+0$ \\
\hline \multirow[t]{2}{*}{ Generic D } & \multirow{2}{*}{$\begin{array}{l}4 \mathrm{M} \text {-storage } \\
40 \mathrm{M} \text {-storage }\end{array}$} & $+0,+2,+2$ & $+0,+1,+0$ & $+0,+0,+0$ & $+0,+0,+0$ \\
\hline & & $+2,+4,+3$ & $+2,+3,+2$ & $+1,+0,+0$ & $+0,+0,+0$ \\
\hline
\end{tabular}

眼液から 1 滴の薬液を回収し, 測定試料とした.こ れら試料中の FML 含量及び濃度を HPLC 法にて 測定した. 試料 $30 \mu \mathrm{L}$ に, $50 \mu \mathrm{g} / \mathrm{mL} p$-ヒドロキシ 安息香酸 $n$-ブチル（内標準物質, メタノールにて 溶解） $80 \mu \mathrm{L}$ を加え，この液をクロマトディスク 4A $(0.45 \mu \mathrm{m}$ ，クラボウ）でろ過後 HPLC に注入 した。高速液体クロマトグラフ装置は LC-20AT （島津製作所）を使用した。カラムは TSKgel ODS-100V $(5 \mu \mathrm{m}, 4.6 \mathrm{~mm}$ I.D. $\times 15 \mathrm{~cm}, \quad \mathrm{TOSOH}$ BIOSCIENCE）を用い, 移動相（メタノール：水 $=7: 3)$ で平衡化した. HPLCへの注入量は $10 \mu \mathrm{L}$ とし, 測定温度はオーブンカラム CTO-20A（島津 製作所）にて $35^{\circ} \mathrm{C}$ を維持した。 また，移動相の流 速は $0.8 \mathrm{~mL} / \mathrm{min}, 254 \mathrm{~nm}$ の紫外部吸収を測定し, 測定時間は 12.5 分とした.

\section{5. 解析 デー夕は平均值 \pm 標準誤差 (S.E.)} として表した。有意差検定は JAM Ver.5.1（日本 SAS 協会）コンピュータプログラムを用いて行っ
た。各々の実験值の有意差比較には Student の $t$-test を用い, $p$ 值が 0.05 未満を有意差ありとした.

結果

\section{1. 短期保管及び長期保管後の FMLO.1 中薬物状} 態とその再分散性の評価 Figure 2 に各種 FML0.1 の短期保管品と長期保管品の点眼容器の底 面部分画像を示す。また， Table 2 にはこれら Fig. 2 で示した保管品を本研究法で用いた手振り混和法 を用いた再分散性試験に適用した際の結果を示す。 いずれの点眼薬においても, 短期・長期保管後, 容 器の底に白濁沈殿物が生じ, 手振り（混和）回数の 増加に従い沈殿物量の減少が認められた.この際, 短期保管品では後発品 B を除き, 3 回混和でほとん どの製品において固化沈殿物は認められなくなつ た. また，長期保管品においても混和回数に従い容 器底面の固化沈殿物は減少し, 後発品 $\mathrm{B}$ を除き, 10 回混和で固化沈殿物は認められなかった。この 

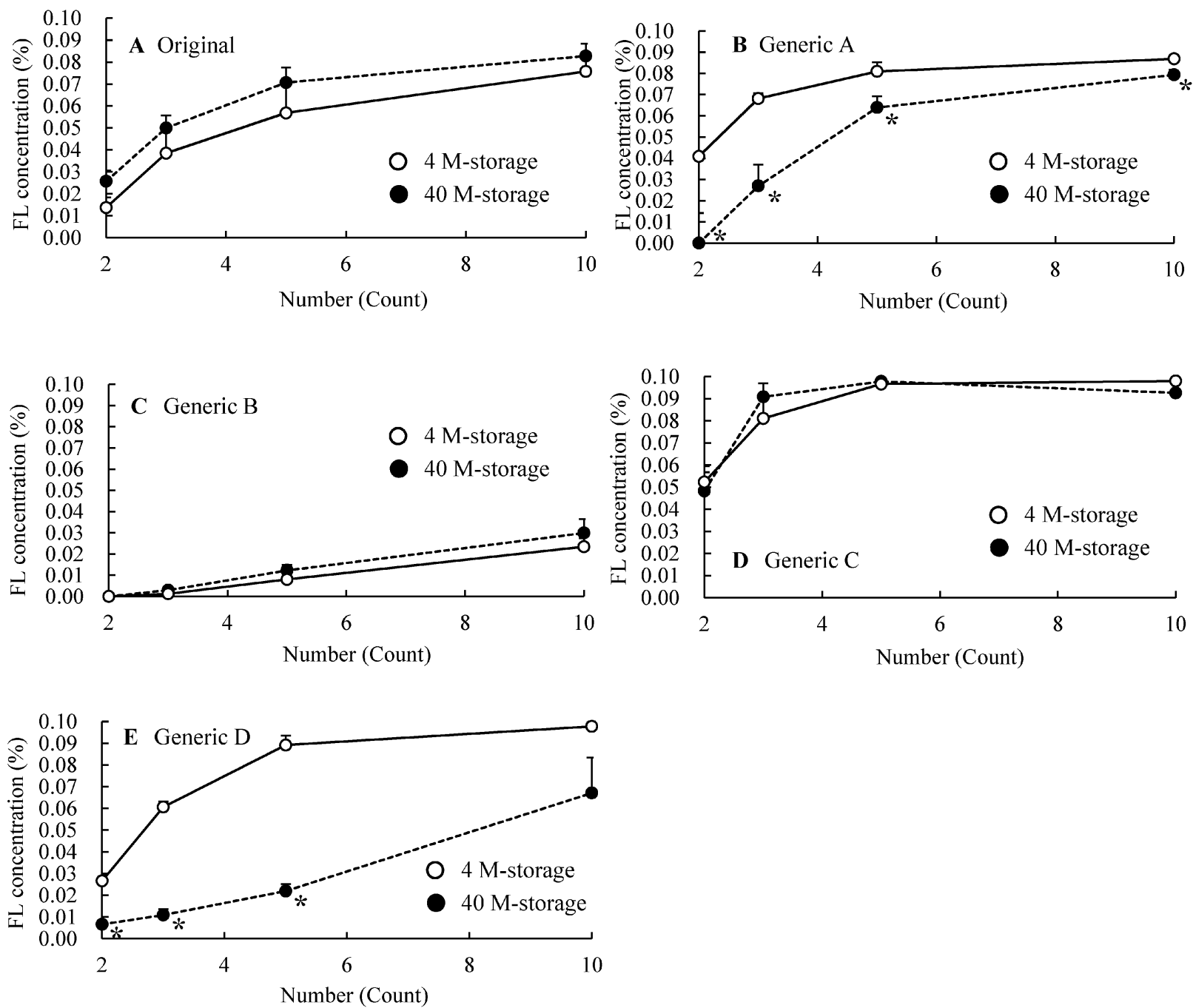

Fig. 3. Effect of Mixing on the FML Concentration in the 1 Drops of FML0.1 Stored for $4 \mathrm{M}$ and $40 \mathrm{M}$ (A) Original. (B) Generic A. (C) Generic B. (D) Generic C. (E) Generic D. Mean \pm S.D. $n=3 .{ }^{*} p<0.05 v$ s. 4 M-storage

ように，短期保管及び長期保管ともに，程度の差は あったが，同様の傾向を示した。一方，10 回混和 後においても固化沈殿物がみられた後発品 $\mathrm{B}$ と他 の点眼薬間の外観上の違いを確認したところ．後発 品 $\mathrm{B}$ では他の点眼容器と異なり, 楕円形の底面で 底面の中心部が盛り上がり，周囲に溝を形成する形 状であった.

\section{2. 短期保管及び長期保管後の FML0.1における} 初回 1 滴中薬物濃度の变化 短期保管品之長期保 管品の各種 FML0.1 の混和回数による初回 1 滴中 濃度の変化を Fig. 3 に示す。すべての製品におい て混和回数の増加に従い, 初回の 1 滴中濃度は高ま り, 先発品において 1 滴あたりの薬物濃度は 10 回 混和で規格値（0.1\%）の約 70\%程度であった．後 発品 A と C もまた 10 回混和で規格值の約 80-90\%
なったが，後発品 B $の 10$ 回混和時の 1 滴当たりの 濃度は $30 \%$ に満たず，均一に再分散されていない 結果となった。一方，後発品 $\mathrm{D}$ は，短期保管では 10 回混和でほぼ規格值に達したが，長期保管では 1 滴中濃度が低下し，保管による再分散能の低下がみ られた．長期保管で大きく 1 滴中濃度に影響が認め られたのは後発品 $\mathrm{D}$ と混和回数が少ない時の後発 品 $\mathrm{A}$ であった。

\section{3. 短期保管及び長期保管後の FML0.1 における} 初回 1 滴中薬物粒子径亡粒子径分布の変化

Figure 4, 5 及び 6 に短期保管品と長期保管品に 対し 10 回混和を行った際の薬物粒子の顕微鏡画像 (Fig. 4)，粒度分布（Fig. 5）及び平均粒子径の変 化（Fig. 6）をそれぞれ示す．懸濁点眼剤中の粒子

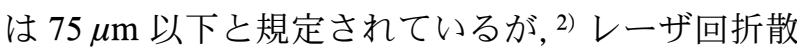




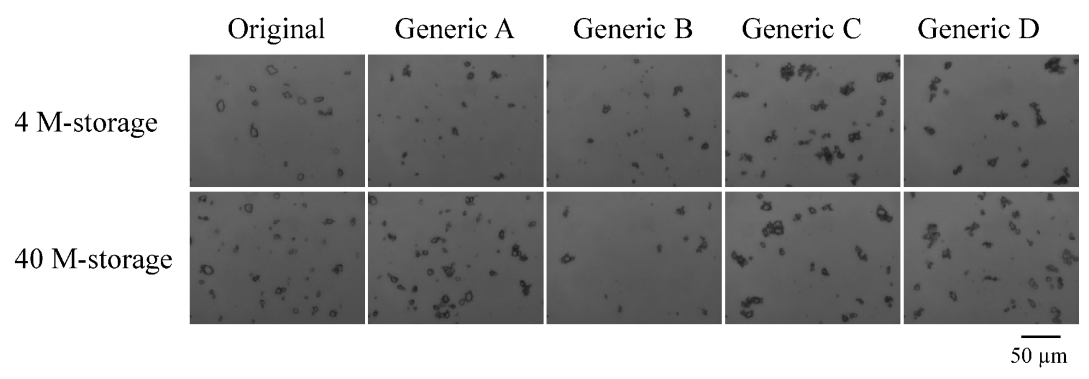

Fig. 4. Image of FML0.1 Stored for $4 \mathrm{M}$ and $40 \mathrm{M}$ The mixing was performed 10 times before the experiment.
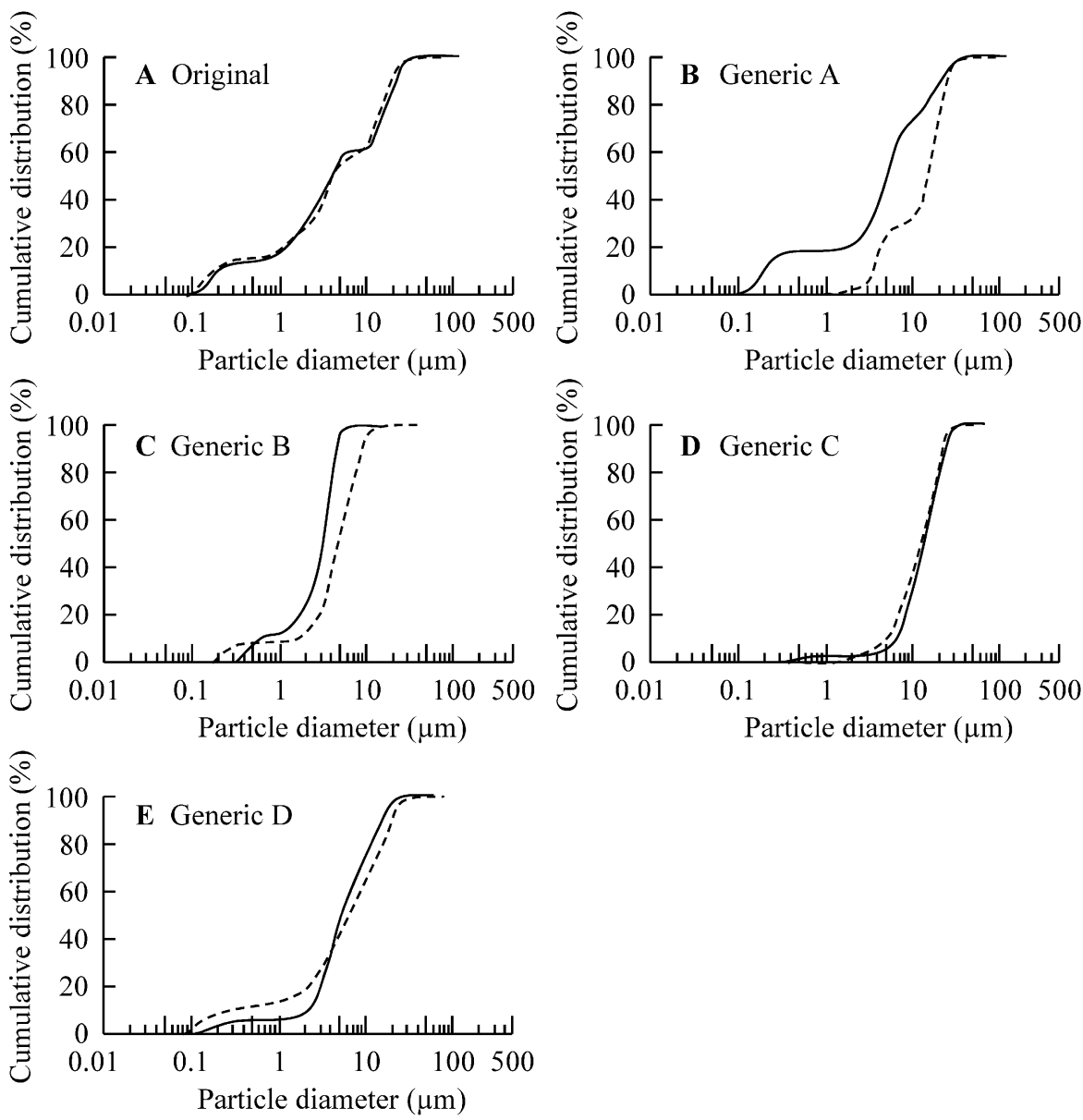

Fig. 5. Changes in Particle Size Frequencies of FML0.1 Stored for $4 \mathrm{M}$ and $40 \mathrm{M}$

(A) Original. (B) Generic A. (C) Generic B. (D) Generic C. (E) Generic D. The mixing was performed 10 times before the experiment. Solid line, 4 Mstorage. Dashed line, $40 \mathrm{M}$-storage.

乱法での観察ではほとんど $30 \mu \mathrm{m}$ 以下であり, $50 \mu \mathrm{m}$ 以上の粒子が認められることは稀であり, い ずれの点眼液においても短期保管品を 10 回混和し た際の粒度分布は，十分に混和（ボルテックスにて 10 秒混和）した際の粒度分布と大きな差はみられ なかった。一方，先発品において短期及び長期保管 ともに 1 滴あたりの薬物粒子径は約 $4 \mu \mathrm{m}$ であっ
た。また，後発品 $\mathrm{B}$ と D においても短期及び長期 保管ともに先発品と同定の粒子径を示したが, 後発 品 $\mathrm{A}$ と C の粒子は先発品のものより粗粒子であっ た. さらに, 後発品 $\mathrm{C}$ では短期及び長期保管品と もに 10 回混和後の粒子径は同程度であったが，長 期保管後の先発品 $\mathrm{A}$ の平均粒子径は短期保管後の 約 3 倍であった. 


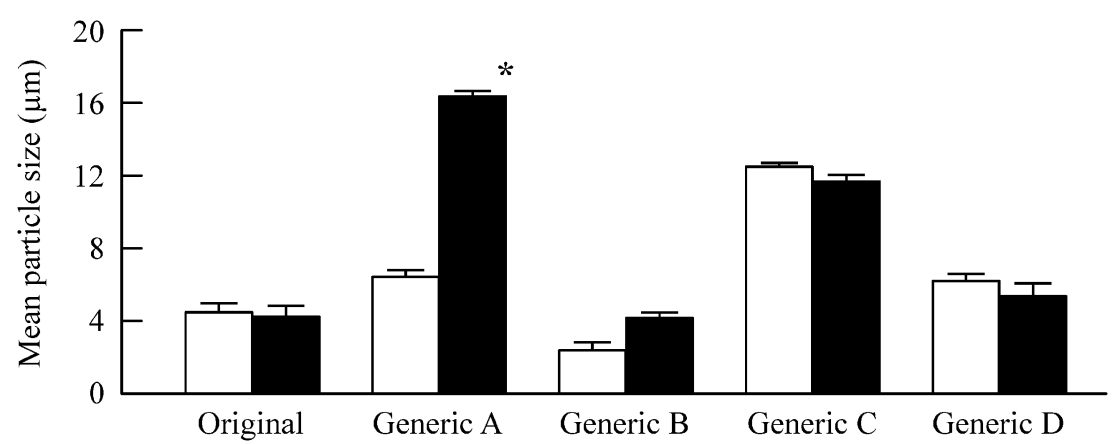

Fig. 6. Comparison of Mean Particle Size of the Original and Generic FML0.1 Stored for $4 \mathrm{M}$ and $40 \mathrm{M}$ The mixing was performed 10 times before the experiment. Mean \pm S.D. $n=3 .{ }^{*} p<0.05 v s .4$ M-storage.

\section{考察}

懸濁製剂を保管した際の物理的な安定性（再分散 性及び粒子径）を検討することは，市販製剤の適正 使用において重要である。本研究では眼領域で用い られる FML0.1 を対象に， 4 又は 40 カ月間保管し た際の薬物粒子径変化を観察するとともに，本研究 法で用いた手振り混和法を用いた混和後の再分散性 及び初回 1 滴中の主薬濃度の変化について検討した.

まずはじめに，4 又は 40 カ月間保管した製剤を 簡単に懸濁した際の，1 滴あたりの薬物濃度及び再 分散性についての検討を行つた．本検討を適切に実 施する上で試験法（混和法）を決定することは重要 である。一般に混和法には以下 3 種が知られてい る; (1) $20 \mathrm{~cm}$ 幅の水平面を毎秒 1 往復水平振とうさ せる方法あるいは男子が強く振とうする方法, ${ }^{3)}$ (2) 容器を回転させる方法, ${ }^{4)}$ (3)懸濁インスリン製剤の 懸濁性評価で使用されるように，手のひらで水平に 往復回転させた後, 上下に往復させる方法5)が採用 されている。このように懸濁製剤の再分散性に関す る評価方法は種々あるが，本研究では懸濁製凨の再 分散性を感度よく検出するため, 急激な力が加わら ない混和法(3) [容器をゆっくり約 $45-90^{\circ}$ の角度で 手振り（混和）する方法］を採用し，検討を行った.

懸濁製剂において難溶性の内容物の沈降に対する 安定性は重力と浮力のバランスによって決まり，分 散質と分散媒の比重差，分散質の大きさ，分散媒の 粘度などによって影響を受ける．理想的には粒子は 凝集することなく，一次粒子として安定に分散し， しかも沈降することなく均一な濃度で浮遊している ことが望まれる，今回，Table 2 に示すように検討 を行った各種 FML0.1 のうち, 後発品 A と D が正
立保管の条件下で長期保管すると底面固化沈殿物の 再分散性が低下することがわかつた。一方，長期保 管による再分散性の低下の程度は製品で異なり，先 発品と後発品 $C$ では再分散性がよく, 長期保管の 影響は受け難い結果となつたが，後発品 B は短期 保管品でも再分散性は良好ではなかった。

次に, 混和後の初回 1 滴中の主薬濃度の変化につ いて検討した（Fig. 3)。これまでの研究では, 点 眼中の 1 滴中濃度あるいは 1 滴中薬物含量を複数滴 の平均值で算出している例も多いが, $\left.{ }^{6}\right)$ 懸濁製㓮の 場合は分散性の問題もあり，また服薬指導で点眼は 1 滴で十分と説明される。また，FML 製剤の製品 間で 1 滴量が異なることは報告されているが, ${ }^{6}$ そ そ の差は微量であり，かつ点眼された薬液のほとんど は涙管を通じて排泄されることから，7) 実施的な 1 滴量の多少よりも薬物濃度が直接影響すると考えら れている.このため本研究では最初の 1 滴（初回 1 滴）を対象に薬物濃度を測定した（Fig. 3)。その 結果，初回 1 滴中の濃度は再分散性に影響され，先 発品と後発品 $\mathrm{B}$ 及び $\mathrm{C}$ は長期保管の影響を受けな かったが，再分散性が長期保管の影響を受ける後発 品 $\mathrm{A}$ と D は短期保管品の方が初回 1 滴濃度は高い 值を示した。一方，長期保管の影響は受けないもの の本条件では再分散性のよくない後発品 B は 10 回 混和でも表示濃度の $30 \%$ 以下の值であった.

これら各種懸濁製剤の物理的安定性の違いを考察 することは極めて重要である．主薬の粒子の成長性 は物理的安定性において大切な因子であるが，今回 検討した各種 FML0.1の短期保管品と長期保管品 の 10 回混和した粒子径を比較すると後発品 A で約 $5 \mu \mathrm{m}$ 程度の増加が認められるものの，先発品を含 め他の後発品では大きな粒子径の変化は認められず 
(Fig. 5), 後発品 A に関しては長期保存で主薬粒子 の凝集が観察された（Fig. 4)。このため主薬の粒 子径の成長が直接䆃濁剂の物理的な安定性への影響 は少ないのではないかと考えられた。また，粘度の 影響も考えられるが，本研究で用いた FML0.1 で 高い粘度を有する製品はなく，再分散性に及ぼす粘 度の影響も考え難い。一方，界面活性剂あるいは水 溶性高分子により分散質と分散媒の固液界面張力を 低下させる方法で再分散性を向上させる方法が知ら れており, Yasueda らは FML0.1に 0.0001-0.01\% （w/v）の HPMC を添加することで表面張力を低下 させ，再分散が向上することを報告している. ${ }^{8)}$ 今 回用いた先発品においても添加剂として界面活性剂 のポリソルベート 80 と分散剤のメチルセルロース を用いられていた（Table 1)。これらは非イオン性 界面活性剂だけでは十分でない再分散性を，セル ロース系高分子を加えることで沈降濃縮した薬物粒 子間にセルロース系高分子が介在して粒子間の接触 頻度を低下させ，その働きによって薬物の凝集性を 緩和し (緩凝集系)，保管時に沈殿するものの再分 散性を向上させているものと考えられる. ${ }^{9)}$ また後 発品 C は他の FML0.1 と異なり，分散剤は配合さ れておらず，界面活性剤のポリソルベート 80 のみ を配合した処方であるが，短期保管品，長期保管品 とも混和回数 3 回以上で再分散可能であった.この 高い再分散性は平均粒子径が $10 \mu \mathrm{m}$ を超える大き な粒子を用いることで再分散性を高めているものと 考察された（Figs. 4 and 6). 一方で, 後発品 A と $\mathrm{D}$ は分散剤としてポリビニルアルコール（部分け ん化物）あるいはメチルセルロースを配合している ものの界面活性剤は配合されておらず，長期保管に よる影響が認められた（Fig. 3)。また，後発品 B は界面活性剤のポリソルベート 80 と分散剂のポリ ビニルアルコール（部分けん化物）が用いられてお り，緩凝集系を狙つた処方の可能性もあるが，再分 散性は今回の被験薬の中で最も悪い結果となつた (Table 2 and Fig. 3). その原因として, 後発品 B の点眼容器の形状が他の点眼容器と異なり, 底面が 楕円形で底面の中心部が盛り上がり周囲に溝を形成 する形状であったこと，また点眼容器はコンパクト でデザイン性はよいが容器上部に空隙が少なく, 混 和（手振り）時に十分擋汼されていない可能性が示 唆された。界面活性剤あるいはポリマーを懸濁剤に
添加していくと，その添加濃度によって分散安定性 が複雑に変化するという報告があり，容器改良と相 まって分散安定性に関して更なる検証を行い，再分 散性の高い製剤改良が可能であると思われる.

Leonard らは各種ステロイド水性懸濁点眼剤に関 する報告において，用時振とうを明記した場合でも 息者の過半数はそれを遵守していないこと，また振 とうされた場合でもほぼ均一な懸濁状態となる前に 使用されていることなどを指摘している. ${ }^{10)}$ 今回の 結果から FML0.1 の服薬指導時に十分な混和が必 要であり，実際に患者が点眼前に十分な混和を実行 しない場合，アドヒアランスの低下が懸念される. さらに一歩踏み込んで服薬指導だけではなく，もし 患者自身による手振り混和が難しく，かつ家族の支 援が受けられない場合には再分散性や初回 1 滴濃度 に優れた後発品を推奨する必要があると考える。さ らに米国で「Patient-Focused Drug Development （患者視点の研究開発，FDA の審査もまた同様に患 者視点でのリスク・ベネフィット比を重要視)」11)の 動きが強まりつつあることを考えると，今後ますま す患者視点に立つ製剤開発が重要となるだろう。一 方で, 本研究では購入後 40 力月という長期保管時 に懸濁分散粒子がどのような状態になるのかを観察 するため，製剤の使用期限を超えた製剤の分散安定 性を評価する形となった。これら使用期限外といつ た因子が再分散性や初回 1 滴中濃度にどの程度影響 するかについても，今後更なる検討が必要である.

利益相反＼cjkstart開示すべき利益相反はない.

\section{REFERENCES}

1) Fujimoto M., Nakamura T., Muraoka E., Jpn. J. Pesticide Sci., 7, 499-506 (1982).

2) The Japanese Pharmacopoeia Seventeenth Edition, [3] Monographs for Preparations p16, 6. Preparations for Ophthalmic Application, 6-1. Ophthalmic Liquids and Solutions.

3) Nagatani K., Oishi T., Honke T., Shinagawa R., J. Jpn. Hosp. Pharm. Assoc., 11, 256-261 (1985).

4) Morishima K., Shiotani K., Japanese Unexamined Patent Application Publication No. Hei 11-279052 (1999).

5) Kawasaki E., Asakura T., Karasawa H., Yoh- 
koh N., J. Jpn. Diabetes Soc., 55, 753-760 (2012).

6) Nagatani K., Oishi T., Honke T., Shinagawa R., Iwasaki S., J. Jpn. Hosp. Pharm. Assoc., 11, 262-266 (1985).

7) Nakada Y., "Seizai no Tatsujin niyoru Seizaigijutsu no Denshou (Gekan) Hikeikoutouyoseizai no Seizaisekki to Seizouhou,', ed. by The Academy of Pharmaceutical Science and Technology, Jiho, Inc., Tokyo, 2013, pp. 105-115.

8) Yasueda S., Inada K., Matsuhisa K., Teraya- ma H., Ohtori A., Eur. J. Pharm. Sci., 57, 377-382 (2004).

9) Yasueda S., Matsuhisa K., Terayama H., Inada K., Japanese Unexamined Patent Application Publication No. 2003-55262 (2003).

10) Leonard A., Andrew H., Lawrence M. S., Am. J. Ophthalmol., 87, 210-214 (1979) .

11) U.S. Food and Drug Administration. CDER Patient-Focused Drug Development:〈https:// www.fda.gov / drugs / development-approvalprocess-drugs / cder-patient-focused-drug-deve lopment $\rangle$, cited 20 November, 2019. 